\title{
ASSESMENT OF TRAP COLOR AND TRAP HEIGHT ABOVE THE GROUND ON THE CAPTURE OF IPS SEXDENTATUS AND THANASIMUS FORMICARIUS
}

\section{PROCJENA boje i visine FEROMONSKE KLOPKE iznad zemlje za ULOV Ips sexdentatus i Thanasimus formicarius}

\author{
Erol AKKUZU'1, Mustafa ŞAHIN², Abdullah UGIŞ', Ebru BAL ${ }^{2}$
}

\begin{abstract}
SUMIMARY
The six-toothed pine bark beetle Ips sexdentatus is one of the most devastating bark beetles of Eurasian pine forests. Pheromone traps are used to monitor and control Ips sexdentatus populations. In this study, the effect of trap color and trap height on the capture of Ips exdentatus and its predator the ant beetle Thanasimus formicarius was investigated. The research was conducted in Pinus sylvestris stands within Yayla Forest Enterprise Chief (Kastamonu-Daday) in Turkey. In the study area, 25 Scandinavian type three-funnel traps of 5 different colors (yellow, white, green, black, and red traps with five replications) were used. Traps were placed at the same height, $1.5 \mathrm{~m}$ above ground. For the second part of the study, a total of 20 traps (5 per height category) was placed $1.0 \mathrm{~m}, 1.5 \mathrm{~m}$, $2.0 \mathrm{~m}$, and $2.5 \mathrm{~m}$ above ground. Traps were controlled at intervals of 7-10 days and captured Ips exdentatus and Thanasimus formicarius were counted. The results of the study were as follows: 1) Significant differences in the number of captures by trap color, and 2) No significant differences in the numbers of Ips sexdentatus and Thanasimus formicarius captured between the trap heights.
\end{abstract}

KEY WORDS: Six-toothed pine bark beetle, ant beetle, trap height, trap color, pine

\section{INTRODUCTION}

\section{UVOD}

Bark beetles, belong to the subfamily Scolytinae within the family Curculionidae (Coleoptera), are one of the most destructive groups among the xyloephagous species on trees (Cebeci and Baydemir 2018). Although most of the bark beetle species are secondary pests, defined as infesting freshly killed trees or killing living trees of subnormal physiological condition (Rudinsky 1962, Stark 1982, Lausch et al. 2013, Lieutier et al. 2016), they cause tremendous amount of mortality and/or growth loss of conifers.
The six-toothed pine bark beetle, Ips sexdentatus (Boerner, 1776), is one of the most devastating pests of the most of the European pine forests (Jactel and Gaillard, 1991) feeding predominantly on Pinus spp. but during outbreaks may attack even Picea spp. (Rener and Maja 2001, Ozcan et al. 2011, Avtzis et al. 2019). Althouh this species mainly prefers trees that are somehow wekakened or otherwise under stress, it can even attack and kill healthy trees at high population levels (Rossi et al. 2009, Pineau et al. 2017).

Various control and monitoring methods have been established to reduce bark beetle's adverse effects on forests.

\footnotetext{
'Prof. Dr. Erol Akkuzu, Corresponding author: eakkuzu@kastamonu.edu.tr; Res.Asst. Abdullah Ugış, augis@kastamonu.edu.tr; Kastamonu University, Faculty of Forestry, 37150, Kastamonu, Turkey

${ }^{2}$ MSc Student, Kastamonu University, Institute of Science and Technology, Kastamonu-37150, Turkey
} 
Among them, commercially produced pheromone traps against bark beetles and wood-boring insects have been used in forestry practice for more than 40 years (Galko et al. 2016).

The eyes of scolytids have about 100-240 ommatidia, relatively less than many insects (Chapman 1972, Byers et al. 1989). Although scolytids have low visual acuity (Byers et al. 1989, Byers 1995), many factors such as trap design and shape may influence the number of pests captured (McLean and Borden 1979, Lindgren et al. 1983, Borden et al. 1986).

Thanasimus formicarius (Linnaeus, 1758) (Col. Cleridae), one of the main predators of Ips sexdentatus (Martin et al. 2013), are saproxylic predators of Scolytinae (bark beetles), both as adults and as larvae (Thomaes et al. 2017). Although pheromone traps are used for monitoring and mass trapping of bark beetles, there are some negative effects on natural enemies. Many insect predators are attracted to pheromone traps and thus are removed along with target beetles (Stephen and Dahlsten 1976, Gregoire et al. 1992, Seybold 1993, Ross and Daterman 1995, Valkama et al. 1997, Dahlsten et al. 2003).

Trap efficacy of pheromone baited traps for bark beetles is affected by many factors: trap color (Paraschiv et al. 2012), trap types (Galko et al. 2016), pheromone dispensers (Zahradníková and Zahradník 2017), and trap placement (Brar et al. 2012, Dodds 2014).

The aim of this study was to compare the positive effects of trap colors and trap heights on the capture of Ips sexdentatus and their negative effects on Thanasimus formicarius.

\section{MATERIAL AND METHODS MATERIJALI I METODE}

\section{Study area - Područje istraživanja}

The study area Forest Enterprise Chief of Kastamonu-Yayla $\left(41^{\circ} 24^{\prime} 52^{\prime \prime} \mathrm{N}-41^{\circ} 31^{\prime} 42^{\prime \prime} \mathrm{E}\right)$ is situated in Western Blacksea region of Turkey. The total area of the study area is 9259.3 ha out of which 6693.9 ha covered with forests. Sites are located on the southern inclination and at altitudes ranging from 1200-1270 m asl.

The main tree species of the study area is Scoth pine (Pinus sylvestris), covering about $90 \%$ of the stem basal area mixed with Pedunculate oak (Quercus robur) and Uludağ fir (Abies bornmülleriana).

\section{Experimental Design and Procedure - Eksperimentalni dizajn i postupak}

The study was conducted from June 9 to August 18, 2017 in Scoth pine dominated stands mixed with pedunculate oak and Uludag fir. SMC IPSEK lures targeted for Ips sexdentatus were used in this sdudy. The active ingredient in the lures was $100 \mathrm{mg}$ Ipsdienol/Dispenser. The lure was replaced every 4 weeks on each pheromone trap. The pheromone traps were checked at 7-10 day intervals from June to August 2017. The captured insects were collected in the field and brought into the Entomology Laboratory of Kastamonu University Faculty of Forestry for identification, counting, and photographing.

For the firsth experiment, five different color of traps (black, white, yellow, red and green) were compared to determine the effect of color on the capture of Ips sexdentatus and Thanasimus formicarius. Scandinavian type three funnel traps were used for the experiment and were hung at a height of $1.5 \mathrm{~m}$ above the ground. The distance between traps was about $30 \mathrm{~m}$, and each trap was about $5 \mathrm{~m}$ away from the nearest tree. A total of 25 traps were installed and each trap color was represented by five traps (replications) per location. For the second experiment, four black colour Scandinavian type three funnel traps were hung at heights of 1.0, 1.5, 2.0, and $2.5 \mathrm{~m}$ as one set to compare the effect of trap height on capturing the pest Ips sexdentatus and the predator Thanasimus formicarius. Five sets of traps (total of 20 traps) were placed along a line in west-easth direction in the field. The distance between traps was about $50 \mathrm{~m}$.

\section{Statistical Analysis - Statistička analiza}

All statistical analyses were performed using SPSS 22 software. The normality of the distributions was tested using a Kolmogorov-Smirnov and Shapiro-Wilk tests. Trap catch data were subjected to Kruskal-Wallis test at a significance limit of $\mathrm{p}<0.05$ followed by multiple comparison test (Post hoc Dunn's test). Pearson's correlation analysis was also used to investigate the corelations between the pest Ips sexdentatus and associated predator Thanasimus formicarius.

\section{RESULTS AND DISCUSSION REZULTATI I RASPRAVA}

\section{Trap color - Boja klopki}

In the color-response experiment the highest number of Ips sexdentatus was captured by black color traps followed by red, green, yellow and the lowest was white color trap. Si-

Table 2. Effect of trap colors on Ips sexdentatus and Thanasimus formicarius capture (Kruskal-Wallis Test)

Tablica 2. Učinak boja klopki na ulov Ips sexdentatus i Thanasimus formicarius (Kruskal-Wallisov Test)

$\begin{array}{lcc}\text { Chi-square } & \text { I. sexdentatus } & \text { T. formicarius } \\ \text { Hi-kvadrat } & 15,063 & 7,832 \\ \text { Df } & 4 & 4 \\ \begin{array}{l}\text { Asymptotic significance } \\ \text { Asimptotski značaj }\end{array} & , 005 & , 098\end{array}$


Table 3. Post hoc Dunn's test of Ips sexdentatus according to trap color

Tablica 3. Post hoc Dunnov test za Ips sexdentatus prema boja klopki

\begin{tabular}{|c|c|c|c|c|c|}
\hline $\begin{array}{l}\text { Sample-1 - Sample-2 } \\
\text { Uzorak 1- Uzorak } 2\end{array}$ & $\begin{array}{c}\text { Test Statistic } \\
\text { Testna statistika }\end{array}$ & $\begin{array}{l}\text { Standard Deviation } \\
\text { Standardno odstupanje }\end{array}$ & $\begin{array}{c}\text { Standard Test Statistic } \\
\text { Standardna testna statistika }\end{array}$ & $\begin{array}{l}\text { Significance } \\
\text { Značajnost }\end{array}$ & $\begin{array}{l}\text { Modified Significance } \\
\text { Modificirana značajnost }\end{array}$ \\
\hline $\begin{array}{l}\text { White - Green } \\
\text { Bijelo - Zeleno }\end{array}$ & 16,750 & 14,106 & 1,187 & 0,235 & 1,000 \\
\hline $\begin{array}{l}\text { White - Yellow } \\
\text { Bijelo - Žuto }\end{array}$ & 23,940 & 14,106 & 1,697 & 0,090 & 0,897 \\
\hline $\begin{array}{l}\text { White - Red } \\
\text { Bijelo - Crveno }\end{array}$ & $-35,080$ & 14,106 & $-2,487$ & 0,013 & 0,129 \\
\hline $\begin{array}{l}\text { White - Black } \\
\text { Bijelo - Crno }\end{array}$ & 51,530 & 14,106 & 3,653 & 0,000 & 0,003 \\
\hline $\begin{array}{l}\text { Green - Yellow } \\
\text { Zelena - Žuta }\end{array}$ & 7,190 & 14,106 & 0,510 & 0,610 & 1,000 \\
\hline $\begin{array}{l}\text { Green - Red } \\
\text { Zeleno - Crveno }\end{array}$ & $-18,330$ & 14,106 & $-1,299$ & 0,194 & 1,000 \\
\hline $\begin{array}{l}\text { Green - Black } \\
\text { Zelena - Crna }\end{array}$ & $-34,780$ & 14,106 & $-2,466$ & 0,014 & 0,137 \\
\hline $\begin{array}{l}\text { Yellow - Red } \\
\text { Žuto - Crveno }\end{array}$ & $-11,140$ & 14,106 & $-0,790$ & 0,430 & 1,000 \\
\hline $\begin{array}{l}\text { Yellow - Black } \\
\text { Žuta - Crna }\end{array}$ & $-24,590$ & 14,106 & $-1,956$ & 0,050 & 0,505 \\
\hline $\begin{array}{l}\text { Red - Black } \\
\text { Crveno - Crno }\end{array}$ & 16,450 & 14,106 & 1,166 & 0,244 & 1,000 \\
\hline
\end{tabular}

Confidence Level: 0,05

Razina pouzdanosti: 0,05

gnificant differences in the mean total capture of Ips sexdentatus were noted among the five trap colors $(\mathrm{df}=4, \mathrm{p}<$ 0.005) (Figure 3). Post hoc Dunn's test showed that significantly more Ips sexdentatus were captured by black traps than white ones $(\mathrm{p}<0.003)$ (Table 2). No significant differences were occurred among the other trap colors (Table 3). Although there were no statistically significant differences in numbers of Thanasimus formicarius captured between the trap colors $(\mathrm{p}<0.098)$, white-color trap was the least attractive pheromone trap followed by yellow, red, green, and black traps (Fig. 1).

Pearson correlation analysis was performed to determine the relationship between the number of Ips sexdentatus and Thanasimus formicarius captured by pheromone traps. The test

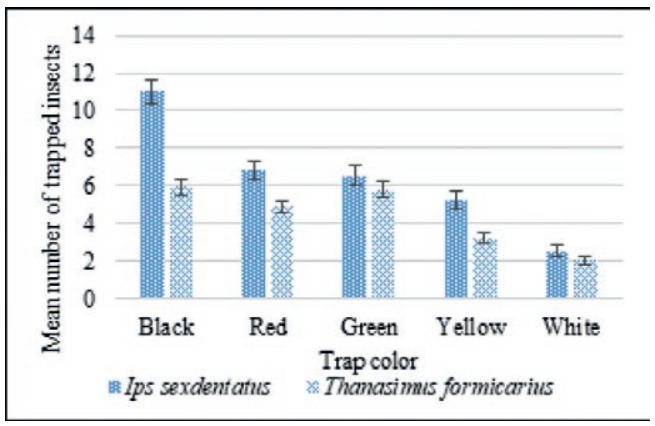

Figure 1. Mean catch ( $\pm \mathrm{SE}$ ) of Ips sexdentatus and Thanasimus formicarius according to tested pheromone trap colors.

Slika 1. Srednji ulov ( \pm SE) Ips sexdentatus i Thanasimus formicarius u odnosu na boje ispitivanih feromonskih klopki.
Table 4. Correlation analysis for pheromone trap colors

Tablica 4. Korelacijska analiza boja feromonskih klopki

\begin{tabular}{|c|c|c|c|}
\hline & & I. sexdentatus & T. formicarius \\
\hline \multirow{3}{*}{ I. sexdentatus } & $\begin{array}{l}\text { Pearson Correlation } \\
\text { Pearsonova korelacija }\end{array}$ & 1 & $0,589^{* *}$ \\
\hline & $\begin{array}{l}\text { Significance } \\
\text { Značajnost }\end{array}$ & & 0,000 \\
\hline & N & 250 & 250 \\
\hline \multirow{3}{*}{ T. formicarius } & $\begin{array}{l}\text { Pearson Correlation } \\
\text { Pearsonova korelacija }\end{array}$ & $0,589 * *$ & 1 \\
\hline & $\begin{array}{l}\text { Significance } \\
\text { Značajnost }\end{array}$ & 0,000 & \\
\hline & $\mathrm{N}$ & 250 & 250 \\
\hline
\end{tabular}

** Correlation is significant at 0.01 level.

** Korelacija je značajna na razini 0,01 .

indicated that a significant and positive relationship existed between the pest and the predator $(\mathrm{p}<0.01)$ (Table 4$)$.

In this study, dark traps (Black, Green and Red) were found to be more effective in attracting insects than light traps in general (Yellow and White). This result is consistent with Chen et al. (2009)'s findings on I. duplicatus. In addition, Strom et al. (1999) and Strom and Goyer (2001) showed that funnel-type black-colored traps caught more Dendroctonus frontalis and D. brevicomis than white-colored traps. Dubbel et al. (1985) found that for I. typographus and Trypodendron lineatum no significant differences were observed in clear, black, green, grey and redbrown traps, whereas catches in white traps were significantly lower. Mizell III and Tedders (1999) reported that dark colored 


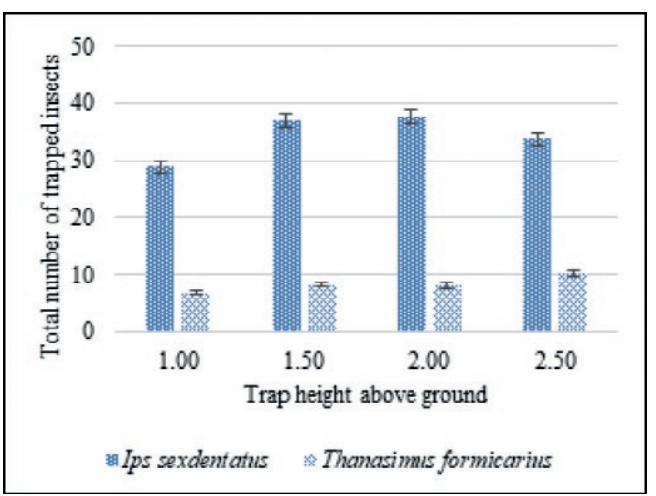

Figure 2. Mean catch $( \pm \mathrm{SE})$ of Ips sexdentatus and Thanasimus formicarius according to tested pheromone trap heighs above ground.

Slika 2. Prosječni ulov ( \pm SE) Ips sexdentatus i Thanasimus formicarius prema visini ispitivane feromonske klopke iznad zemlje.

Table 5. Effect of trap installation height on Ips sexdentatus and Thanasimus formicarius capture (Kruskal-Wallis Test)

Tablica 5. Učinak visine postavljanja klopke za Ips sexdentatus i Thanasimus formicarius (Kruskal-Wallisov test)

$\begin{array}{lcc} & \text { I. sexdentatus } & \text { T. formicarius } \\ \text { Chi-square } & 2,188 & 2,845 \\ \text { Hi-kvadrat } & 3 & 3 \\ \text { Df } & , 534 & , 416 \\ \text { Asymptotic significance } \\ \text { Asimptotska značajnost }\end{array}$

(black and brown) tedders traps were more effective for Hylobius pales (Herbst) and Pachylobius picivorus (Germar) insects than yellow-colored and white-colored traps. Mizell III and Tedders (1999) stated that due to the dark color of coniferous trees' stem, the insects damaging these trees may tend to dark traps.

Yellow colored sticky traps resembling the color of flowers are used in order to catch insect species of agricultural pests. On the other hand, light colors (white or yellow) probably resemble the color of non-host angiosperm tree trunks, which is a strong visual barrier for conifer bark beetles

Table 6. Correlation analysis for pheromone trap hanging heights Tablica 6. Korelacijska analiza visina na kojima su postavljene feromonske klopke

\begin{tabular}{|llcc} 
& & I. sexdentatus & T. formicarius \\
I. sexdentatus & $\begin{array}{l}\text { Pearson Correlation } \\
\text { Pearson korelacija } \\
\text { Significance }\end{array}$ & 1 & $0,524^{* *}$ \\
& $\begin{array}{l}\text { Značajnost } \\
\text { N }\end{array}$ & 200 & 0,000 \\
& $\begin{array}{l}\text { Pearson Correlation } \\
\text { T. formicarius }\end{array}$ & $0,524^{* *}$ & 200 \\
& $\begin{array}{l}\text { Pearson korelacija } \\
\text { Significance }\end{array}$ & 0,000 & 1 \\
& Značajnost & 200 & 200
\end{tabular}

** Correlation is significant at 0.01 level.

** Korelacija je značajna na razini 0,01 .
(Strom et al. 1999, Strom and Goyer 2001, Campbell and Borden 2009).

In this study, although there was no significant difference, dark-color traps (black, green, red) attracted more Thanasimus formicarius than light ones (yellow and white). Since black color traps are widely used today for monitoring and mass trapping of bark beetles, this result creates an undesirable situation in terms of biological control of bark beetles.

\section{Trap installation height - Visina postavljanja klopke}

Pheromone traps set at a height of $2 \mathrm{~m}$ had the highest mean attractiveness for Ips sexdentatus, followed by $1.5 \mathrm{~m}, 2.5 \mathrm{~m}$, and $1 \mathrm{~m}$. On the other hand, the number of trapped Thanasimus formicarius at $2.5 \mathrm{~m}$-trap height was the highest, followed by $2 \mathrm{~m}, 1.5 \mathrm{~m}$, and $1 \mathrm{~m}$ (Fig. 2). The results howewer showed that trap height on Ips sexdentatus $(\mathrm{p}<0.534)$ and Thanasimus formicarius $(\mathrm{p}<0.416)$ attraction was not significant (Table 5).

Chen et al. (2009) partially supports our findings in their study on I. duplicatus. Chen et al. (2009) reported that the trap height at 1.5-2 m captured more insects then the trap height at ground level or 3.5-4 m. According to Göktürk et al. (2010), the most effective trap height for I. typographus was $2 \mathrm{~m}$, followed by a height of $5,3,4$, and as in our findings the least effective was $1 \mathrm{~m}$-height traps. Göktürk et al. (2010) evaluated that shrub and herbaceous cover or forest floor may interrup the functioning of $1 \mathrm{~m}$ height-pheromone traps, and since the flying height of I. typographus is about $2 \mathrm{~m}$, most of the pest may be captured by the traps hung at height of $1 \mathrm{~m}$.

Pearson correlation analysis was performed to determine the relationship between the number of Ips sexdentatus and Thanasimus formicarius captured by pheromone traps depending on trap heights from the ground (Table 4.10). The test indicated that a significant and positive relationship existed between the pest and the predator $(\mathrm{p}<0.01)$ (Table 6).

Thanasimus formicarius is attracted to bark beetle pheromones and host plant volatile compounds that bark beetles use for locating host trees and their mates (Bakke and Kvamme 1981, Kohnle and Vite 1984, Tommeras 1988, Seybold et al. 2006). Indeed, Lopez and Goldarazena (2012) reported that the most common predator in the traps was Thanasimus formicarius in their study. This proves that Thanasimus formicarius has a strong orientation towards Ips sexdentatus pheromone.

\section{ACKNOWLEDGEMENT ZAHVALA}

This paper is produced from the master thesis of Mustafa Şahin titled "Effect of Type, Color and Hanging Height of Ips sexdentatus Pheromone Traps on Capture Rates" at Kastamonu University, Institute of Science and Technology. 


\section{REFERENCES}

\section{LITERATURA}

- Avtzis, D. N., F. Lakatos, D. Gallego, M. Pernek, M. Faccoli, R. Wegensteiner, C. Stauffer, 2019: Shallow genetic structure among the European populations of the six-toothed bark beetle Ips sexdentatus (Coleoptera, Curculionidae, Scolytinae). Forests, 10,136

- Bakke, A., T. Kvamme, 1981: Kairomone response in Thanasimus predators to pheromone components of Ips typographus. Journal of Chemical Ecology, 7(2): 305-312

- Borden, J. H., D.W.A. Hunt, D. R. Miller, K. N. Slessor, 1986: Orientation in forest Coleoptera: an uncertain outcome of responses by individual beetles to variable stimuli, pp. 97-109. In T. L. Payne, M.C.B., C.E.J. Kennedy [eds.], Mechanisms in insect olfaction. Clarendon, Oxford, UK.

- Brar G. S., J. L. Capinera, S. Mclean, P. E. Kendra, R. C. Ploetz, J. E. Peña, 2012: Effect of trap size, trap height and age of lure on sampling Xyleborus glabratus (Coleoptera: Curculionidae: Scolytinae), and its flight periodicity and seasonality. The Florida Entomologist, 95(4): 1003-1011

- Byers, J. A., 1995: Host-tree chemistry affecting colonization in bark beetles, pp. 154-213. In R. T. Carde', W. J. Bell [eds.], Chemical ecology of insects 2. Chapman and Hall, New York.

- Byers, J. A., O. Anderbrant, J. Löqvist, 1989: Effective attraction radius: a method for comparing species attractants and determining densities of flying insects. J. Chem. Ecol. 15: 749-765

- Campbell, S. A., J. H. Borden, 2009: Additive and synergistic integration of multimodal cues of both hosts and non- hosts during host selection by woodboring insects. Oikos, 118(4): 553-563

- Cebeci, H.H., M. Baydemir, 2018: Predators of bark beetles (Coleoptera) in the Balikesir region of Turkey. Revista Colombiana de Entomología 44 (2): 283-287

- Chapman, J.A., 1972: Ommatidia numbers and eyes in scolytid beetles. Ann Entomol Soc Amer 65: 550-553

- Chen, G., Q. H. Zhang, Y. Wang, G. T. Liu, X. Zhou, J. Niu, F. Schlyter, 2009: Catching Ips duplicatus (Sahlberg)(Coleoptera: Scolytidae) with pheromonebaited traps: optimal trap type, colour, height and distance to infestation. Pest Management Science: formerly Pesticide Science, 66(2): 213-219

- Dahlsten D.L., D.L. Six, N. Erbilgin, K.F. Raffa, A.B. Lawson, D.L. Rowney, 2003: Attraction of Ips pini (Coleoptera: Scolytidae) and Its Predators to Various Enantiomeric Ratios of Ipsdienol and Lanierone in California: Implications for the Augmentation and Conservation of Natural Enemies. Environmental Entomology, 32(5): 1115-1122

- Dodds, K., 2014: Effects of trap height on captures of arboreal insects in pine stands of northeastern United States of America. The Canadian Entomologist, 146(1): 80-89

- Dubbel, V., K. Kerck, M. Sohrt, S. Mangold, 1985: Influence of trap color on the efficiency of bark beetle pheromone traps 1, 2. Zeitschrift für angewandte Entomologie, 99(1-5): 59-64

- Galko J., C. Nikolov, A. Kunca, J. Vakula, A. Gubka, M. Zúbrik, S. Rell, B. Konôpka, 2016: Effectiveness of pheromone traps for the European spruce bark beetle: a comparative study of four commercial products and two new models. Lesn. Cas. For. J. 62: $207-215$

- Göktürk, T., M. S. Özkaya, Y. Aksu, 2010: Feromon Tuzaklarının Asılma Yüksekliklerinin Böcek Yakalama Oranı Üzerine Et- kileri. III. Ulusal Karadeniz Ormanc1lık Kongresi, 20-22 Mayıs, Cilt: IV Sayfa: 1336-1343

- Gregoire, J. C., D. Coullien, A. Drumont, H. Meyer, W. Francke, 1992: Semiochemicals and the management of Rhizophagus grandis Gyll (Coleoptera: Rhizophagidae) for the biocontrol of Dendroctonus micans Kug (Coleoptera: Scolytidae). Angew. Entomol. 114: 110-112

- Jactel, H., J. Gaillard, 1991: A preliminary study of the dispersal potential of Ips sexdentatus with an automatically recording flight mill. Journal of Applied Entomology 112: 138-145

- Kohnle, U., J. P. Vité, 1984: Bark beetle predators: Strategies in the olfactory perception of prey species by clerid and trogositid beetles 1. Zeitschrift für angewandte Entomologie, 98(1-5): 504508

- Lausch, A. M. Heurich, L. Fahse, 2013: Spatio-temporal infestation patterns of Ips typographus (L.) in the Bavarian Forest National Park, Germany. Ecological Indicators, 31: 73-81

- Lieutier, F., Z. Mendel, M. Faccoli, 2016: Bark beetles of Mediterranean conifers, In: Paine T., F. Lieutier (ed), Insects and diseases of Mediterranean forest systems. Springer, Cham. https:// doi.org/10.1007/978-3-319-24744-1-6.

- Lindgren, B. S., J. H. Borden, L. Chong, L. M. Friskie, D. B. Orr, 1983: Factors inßuencing the eficiency of pheromone-baited traps for three species of ambrosia beetles (Coleoptera: Scolytidae). Can. Entomol. 115: 303-313

- Lopez, S., A. Goldarazena, 2012: Flight dynamics and abundance of Ips sexdentatus (Coleoptera: Curculionidae: Scolytinae) in different sawmills from northern Spain: Differences between local Pinus radiata (Pinales: Pinaceae) and southern France incoming P. pinaster timber. Psyche, 1-6

- Martín A., I. Etxebeste, G. Pérez, G. Álvarez, E. Sánchez, J. Pajares, 2013: Modified pheromone traps help reduce bycatch of bark-beetle natural enemies. Agricultural and Forest Entomology, 15: 86-97

- McLean, J. A., J. H. Borden, 1979: An operational pheromonebased suppression program for an ambrosia beetle, Gnathotrichus sulcatus, in a commercial sawmill. J. Econ. Entomol. 72: 165-172

- Mizell III, R. F., W. L. Tedders, 1999: Evaluation of trap type and color for monitoring Hylobius pales and Pachylobius picivorus in Florida. Florida Entomologist, 615-624

- Ozcan, G.E., M. Eroglu, H.A. Akinci, 2011: Use of pheromonebaited traps for monitoring Ips sexdentatus (Boerner) (Coleoptera: Curculionidae) in oriental spruce stands. Afr. J. Biotechnol. 10: $16351-16360$

- Paraschiv M., G. Isaia, M. L. Duduman, 2012: The effect of intercept ${ }^{\circledast}$ trap color on Ips typographus captures (preliminary results). Bulletin of the Transilvania University of Brasov, Series II: Forestry, Wood Industry, Agricultural Food Engineering, 5(54): 85-90

- Pineau, X., M. Bourguignon, H. Jactel, F. Lieutier, A. Sallé, 2017: Pyrrhic victory for bark beetles: Successful standing tree colonization triggers strong intraspecific competition for offspring of Ips sexdentatus. For. Ecol. Manag. 399: 188-196

- Rener, I., J. Maja, 2001: The six-toothed bark beetle Ips sexdentatus (Boerner, 1767) (Coleoptera: Scolytidae) in the fire site Kojnik. J. For. Sci. 2: 154-155

- Ross, D. W., G. E. Daterman, 1995: Response of Dendroctonus pseudotsugae (Coleoptera: Scolytidae) and Thanasimus undatulus (Coleoptera: Cleridae) to traps with different semiochemicals. J. Econ. Entomol. 88: 106-111 
- Rossi, J.P., J.C. Samalens, D. Guyon, I.Van Halder, H. Jactel, P. Menassieu, D. Piou, 2009: Multiscale spatial variation of the bark beetle Ips sexdentatus damage in a pine plantation forest (Landers de Gascogne, southwestern France). For. Ecol. Manag. 257: 1551-1557

- Rudinsky, J. A., 1962: Ecology of Scolytidae. - Ann. Rev. Ent. 7: 327-348

- Seybold, S. J., 1993: Role of chirality in olfactory-directed behavior: aggregation of pine engraver beetles in the genus Ips (Coleoptera: Scolytidae). J. Chem. Ecol. 19: 1809-1831

- Seybold S.J., D. P. W. Huber, J.C Lee, A.D. Graves, J. Bohlmann, 2006: Pine monoterpenes and pine bark beetles: A marriage of convenience for defence and chemical communication. Phytochemistry Reviews 5:143-178

- Stark, R. W., 1982: Generalized ecology and life cycle of bark beetles. - In: Mitton, J. B. and Sturgeon, K. B. 1982. Bark beetles in North American conifers. A system for the study of evolutionary biology. Univ. Texas Press, Austin, TX, pp. 21-45

- Stephen, F. M., D. L. Dahlsten, 1976: The arrival sequence of the arthropod complex following attack by Dendroctonus brevicomis (Coleoptera: Scolytidae) in ponderosa pine. Can. Entomol. 108: 283-304
- Strom, B. L., R. A. Goyer, 2001: Effect of silhouette color on trap catches of Dendroctonus frontalis (Coleoptera: Scolytidae). Annals of the Entomological Society of America, 94(6): 948-953

- Strom, B. L., L. M. Roton, R. A. Goyer, J.R. Meeker, 1999: Visual and semiochemical disruption of host finding in the southern pine beetle. Ecological Applications, 9(3): 1028-1038

- Thomaes A., A. Drumont, N. Warzée, J.C. Grégoire, E. Stassen, L. Crèvecoeur, N. Berckvens, H. Casteels, D. Vijver, H. Raemdonck, 2017: Bulletin de la Société royale belge d'Entomologie/ Bulletin van de Koninklijke Belgische Vereniging voor Entomologie, 153: 206-214

- Tommeras, B. A., 1988: The clerid beetle, Thanasimus formicarius, is attracted to the pheromone of the ambrosia beetle, Trypodendron lineatum. Experientia, 44(6): 536-537.

- Valkama, H., M. Räty, P. Niemelä, 1997: Catches of Ips duplicatus and other non-target Coleoptera by Ips typographus pheromone trapping. Entomol. Fennica. 8: 153-159

- Zahradníková M., P. Zahradník, 2017: The influence of evaporated pheromone upon the trapping of the spruce bark beetleIps typographus (L.) (Coleoptera: Curculionidae: Scolytinae). Journal of Forest Science, 63(3): 149-152

\section{SAŽETAK}

Šesterozubi borov potkornjak Ips sexdentatus jedan je od najrazornijih potkornjaka u euroazijskim borovim šumama. Za praćenje populacija Ips sexdentatus koriste se feromonske klopke. U ovom radu istraživali smo utjecaj boje i visine klopki na ulov Ips sexdentatus i njegovog predatora Thanasimus formicarius. Istraživanje je provedeno u sastojinama Pinus sylvestris unutar Yayla Forest Enterprise Chief (Kastamonu-Daday) u Turskoj. U području istraživanja koristili smo 25 skandinavskih klopki s tri lijevka u pet različitih boja (žute, bijele, zelene, crne i crvene klopke). Klopke su postavljene na istu visinu, $1,5 \mathrm{~m}$ iznad zemlje. $\mathrm{U}$ drugom dijelu istraživanja postavljeno je ukupno 20 klopki (5 po visinskoj kategoriji) na visine od 1,0 m, 1,5 m, 2,0 m, i 2,5 m iznad zemlje. Klopke smo kontrolirali u intervalima od 7-10 dana i izbrojali smo jedinke Ips sexdentatus i T. formicarius. Dobiveni podaci su obrađeni Kruskal-Wallisovim testovima i testovima višestrukih usporedbi. Rezultati ispitivanja su sljedeći: 1) Značajne razlike u broju ulova u odnosu na boju klopki, 2) Postoji značajan i pozitivni odnos između štetnika i predatora, 3) Nisu utvrđene značajne razlike u broju uhvaćenih jedinki Ips sexdentatus i T. formicarius u odnosu na visine klopki.

KLJUČNE RIJEČI: Šestozubi borov potkornjak, mravasti kornjaš, visina klopke, boja klopke, bor 